\title{
O ACORDO DE LENIÊNCIA COMO INSTRUMENTO DE TUTELA DA DEFESA DA CONCORRÊNCIA NO BRASIL
}

José Maria Ramos

Doutorando em Direito - PUC-PR, Bolsista da Capes. Mestre em Análise Regional, Economista, Bacharel em Direito. Professor do Curso de Ciências Econômicas da Universidade Estadual do Oeste do Paraná - Unioeste, Campus de Francisco Beltrão - PR. Curitiba - PR - Brasil. E-mail: jmramoseco@hotmail.com.br

Oksandro Gonçalves

Doutor em Direito Comercial pela Pontifícia Universidade Católica de São Paulo. Professor dos cursos de graduação e pós-graduação da Pontifícia Universidade Católica do Paraná. Coordenador do Programa de Pós-Graduação em Direito (Mestrado/Doutorado) da Pontifícia Universidade Católica do Paraná. Advogado. Curitiba - PR - Brasil. E-mail: oksandro@cgaadv.com.br

\section{Resumo}

Os países de economia de mercado têm significativas preocupaçóes com as infraçóes à ordem econômica, necessitando constituir marcos regulatórios e mecanismos para tutelar a concorrência econômica, de tal modo que a eficiência econômica seja regida por instrumentos jurídicos determinados pelo Estado. Para mitigar os problemas decorrentes da formaçấo de cartel que impedem a livre concorrência, provocando prejuízos à coletividade, surge o instituto do acordo de leniência, administrado pelo Conselho de Administração e Defesa Econômica - CADE -, órgáo responsável pela prevenção e repressão às infraçôes contra a ordem econômica. $\mathrm{O}$ acordo de leniência é um dos instrumentos mais efetivos utilizados pelas autoridades antitrustes para propiciar a aplicaçáo eficaz da legislação de defesa da concorrência em relação à repressão às condutas anticompetitivas embora haja algumas contradiçóes no campo da ética. Em cumprindo o acordo de leniência, o proponente-delator poderá ter a extinçấo da ação punitiva ou reduçáo de um a dois terços da penalidade aplicável no âmbito administrativo e, no âmbito penal, extingue automaticamente a punibilidade dos crimes contra a ordem econômica.

\section{Palavras-chave}

Antitruste; Análise econômica do direito; Intervenção do Estado; Desenvolvimento; Leniência. 


\section{Abstract}

The market economy countries have significant concerns with the restraint of trade, requiring constitute regulatory frameworks and mechanisms to protect economic competition, so that economic efficiency is governed by legislation determined by the State. To mitigate the problems arising from the formation of a cartel that prevent free competition, causing damage to the community, the Office of the leniency agreement arises, administered by the Board of Directors and Economic Defense - CADE - the body responsible for prevention and repression of offenses against economic order. The leniency agreement is one of the most effective tools used by antitrust authorities to provide effective enforcement of antitrust law as regards the repression of anti-competitive practices although there are some contradictions in the field of ethics. In fulfilling the leniency agreement, the proposing informer may have the extinction of the punitive action or reduction of one to two thirds of the penalty applicable at the administrative level and in the criminal context, automatically terminate the punishment of crimes against the economic order.

\section{Key words}

Antitrust; Law and Economics; State Intervention; Development; Leniency.

\section{Introdução}

O cartel - caracterizado pela formação de acordo, convênio, ajuste ou aliança entre ofertantes, visando à fixação de preços ou quantidades vendidas ou produzidas -, dentre as infraçóes à ordem econômica revela-se potencialmente prejudicial à livre concorrência e à livre iniciativa, haja vista eliminar a concorrência, restringir a capacidade de desenvolvimento tecnológico, bem como promover a imposição de preços ou quantidades ao mercado, prejudicando escolhas dos consumidores, com perdas significativas de bem-estar.

Os carteis são considerados ilegais (o único cartel reconhecido como legalizado é a OPEP - Organização dos Países Exportadores de Petróleo), e, por isso, exige-se a atuação do Estado no desenvolvimento de políticas antitruste com a finalidade de impedir, identificar e punir os agentes econômicos que firmam pactos anticompetitivos, pois a manutenção de um livre mercado corresponde a um interesse difuso, que visa garantir a livre iniciativa que, por sua vez, pressupóe a disputa entre os agentes econômicos.

Considerando a dificuldade de identificar e, consequentemente, de punir atos de cartel, a legislação antitruste evoluiu e introduziu o acordo de leniência, um mecanismo de abrandamento das penalidades em troca de informaçôes que levem à identificação de cartéis, que "difundiram-se e passaram a ser vistos pela comunidade antitruste internacional como a principal ferramenta de investigação à disposição das autoridades" (RIBEIRO; NOVIS, 2010). 
Os acordos de leniência ampliam significativamente a possibilidade de obtenção de provas de carteis, permitindo assim aumentar a probabilidade de condenação desse crime, bem como deter a formação de cartel, ao afetar sua estabilidade, diante do risco da delação.

Assim, este trabalho tem como objetivo analisar o modelo de acordo de leniência introduzido com a Lei n. 12.529/2011, empregado pelo CADE (Conselho de Administração e Defesa da Concorrência), e seus reflexos na persecução cível, penal, bem como, a sua interface com as questóes éticas. Para atender aos objetivos propostos utilizou-se do método de pesquisa bibliográfica, estruturando-se o artigo em quatro seções além desta introdução; a segunda seção apresenta experiências internacionais desenvolvidas nos Estados Unidos e na Comunidade Europeia; a seção três destaca as características do modelo de leniência brasileiro, como os requisitos e os reflexos civil e penal; e a seção quatro aborda questóes éticas que envolvem a política de defesa da concorrência por meio dos acordos de leniência.

\section{Os Acordos de Leniência: A Experiência Norte-Americana, na Comunida- de Europeia e a Brasileira}

O termo leniência vem do latim lenitate, traduzindo a noção de brandura, mansidão, suavidade e, em direito da concorrência, corresponde, segundo Tavares e Giacaglia (2010, p. 78) "à aplicação de uma sanção menos severa, mais suave, em razão da colaboração ao desmantelamento de um cartel”.

Os acordos de leniência, segundo Rodas (2007, p. 22), "são aqueles firmados entre um integrante-delator do cartel e a autoridade antitruste com vistas a reduzir ou afastar as sançôes que seriam aplicadas ao primeiro em troca de cooperação nas investigaçôes". É a possibilidade que os infratores cooperem com as investigaçôes, com a finalidade de prevenir ou reparar dano de interesse coletivo. Para Mello (2008, p. 586), acordo de leniência "é uma tentativa de, pela via jurídica, desmantelar organizaçóes que degeneram o ambiente de livre competição entre os agentes de mercado".

Atualmente, o acordo de leniência é visto como uma importante ferramenta para preservar os pilares da livre concorrência, como será visto na experiência comparada.

\subsection{A Experiência Norte-Americana}

Os EUA foram pioneiros a instituir uma política de leniência em 1978, contudo, essa experiência apresentou poucos resultados porque a celebração do acordo, a concessão de benefícios - anistia (amnesty) das multas e de um processo criminal - não era automática, estando sujeita ao poder discricionário da Divisão Antitruste do Departamento de Justiça. 
Com a finalidade de reduzir a ação discricionária e estender benefícios a potenciais delatores, o programa norte-americano foi revisado em 1993, e passou a ser denominado Corporate Leniency Policy, instituindo três novas formas de abordagem de investigação e punição de carteis.

(i) isenção total, imediata e automática das penalidades em relação às empresas que colaboram com a agência antitruste, antes do início das investigações;

(ii) a possibilidade de a leniência ser concedida, excepcionalmente, após iniciada a investigação, desde que as autoridades não disponham de provas para a condenação;

(iii) a possibilidade de empregados, diretores e outros membros da empresa que cooperarem com as autoridades antitruste poderem ser protegidos das acusaçóes criminais (RODAS, 2007, p. 24).

Com essas alteraçóes o programa mostrou-se fundamental no combate aos carteis, conforme apontam os dados de Griffin (2003), tanto que no período de 1978 até 1993 a média de celebração de acordos foi de aproximadamente uma por ano, e com a nova política, a partir de 1993, o número de celebraçóes subiu para uma por mês, sendo que entre outubro de 2002 e março de 2003 o número de celebraçóes de acordos de anistia pulou para três por mês.

O Corporate Leniency Policy também possibilita a chamada anistia adicional (amnnesty plus), que, segundo Rodas, permitiu que outros cartéis, em outros mercados, fossem denunciados (2007, p. 24):

As autoridades norte-americanas perceberam ser comum que uma empresa participante de um cartel em um mercado, fazia igualmente parte de outros carteis. Em vista disso, de forma pró-ativa, passaram a oferecer acordos de leniência para empresas, já formalmente investigadas por práticas de carteis, com relação a outros carteis em distintos mercados de que também fossem partícipes. Assim, ainda que uma empresa não pudesse ser beneficiada com o perdão total da pena decorrente do primeiro cartel sob investigaçáo, a prestação de informaçóes em relação ao segundo cartel levaria ao afastamento de condenação no que se refere a este, além da redução da pena com relaçáo ao primeiro (o plus). Se a empresa decidir não reportar o envolvimento em um eventual segundo cartel, ela assume o risco de que, caso o conchavo seja descoberto, as penalidades sejam muito maiores em razão da reincidência.

A ideia da anistia adicional permite ao agente econômico que está sob investigação pela prática de cartel em um mercado, firmar acordo de leniência em outro mercado cartelizado do qual faça parte, desde que a autoridade antitruste não tenha conhecimento e o agente cumpra todos os requisitos legais. Assim, ele poderá obter redução da pena no 
cartel que está em investigação e a anistia no qual firmou acordo de leniência, beneficiando-se duplamente, mas em diferentes medidas.

Para estimular o programa de leniência norte-americano, foi publicado, em 29 de outubro de 2003, o Antristrust Criminal Penalty Enhancement and Reform Act of e, em 22 de junho de 2004, o Antristrust Criminal Penalty Enhancement and Reform Act of , que ampliou penalidades e multas. $\mathrm{O}$ primeiro aumentou a multa imposta para a empresa participante de cartel de dez milhóes pra cem milhóes de dólares; e o segundo aumentou a multa ao empresário participante de cartel de trezentos e cinquenta mil dólares para um milhão de dólares e a pena de prisão aumentou de três para dez anos (GPO - Government Publishing Office, 2004).

O sucesso do programa de leniência corporativa norte-americano, segundo Salomi (2012, p.143) se deve a três fatores preponderantes: "a ameaça de aplicação de penalidades severas, o temor da punição e a transparência na política de atuação da agência”. Reflexo disso pode ser observado nos valores arrecadados pela aplicação de multas decorrentes de punição das atividades de carteis, que só no ano fiscal ${ }^{1}$ de 2014 ultrapassaram os $\$ 1.8$ bilhôes de dólares, como demonstra os dados no gráfico 01 .

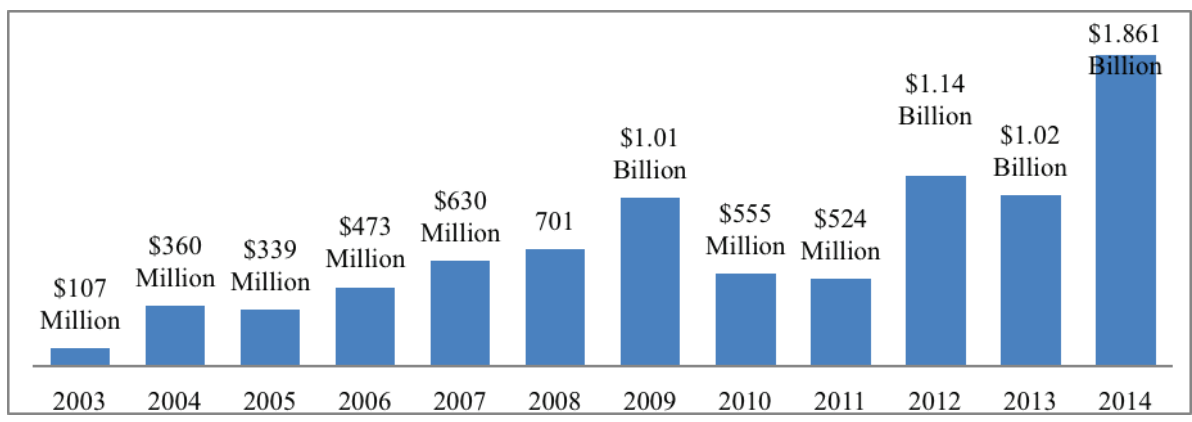

Gráfico 01- Multas aplicadas por crimes antitruste nos Estados Unidos da América no período de 2003 a 2014, no ano fiscal.

Fonte: Department of Justice, Criminal program, 2014.

\subsection{A Experiência da Comunidade Europeia}

Com o Tratado de Roma de 1957, que instituía um mercado comum para seus signatários iniciais (França, Itália, Alemanha, Bélgica, Holanda, Luxemburgo), lançou-se as bases para um direito da concorrência europeu. Para Bagnole (2005, p. 201), "no campo

1 O ano fiscal norte americano encera em 30 de setembro. 
da concorrência o tratado tinha como objetivo a superação da divisão do espaço econômico europeu em favor de um mercado cada vez mais integrado, onde as empresas tivessem liberdade de competir" bem como evitar o aparecimento de monopólios, práticas concertadas de empresas entre outros elementos que restrinjam a concorrência.

A Comunidade Europeia também desenvolveu seu programa de leniência, que por intermédio da Comissão Europeia, órgão comunitário responsável pela defesa da concorrência, lançou, em 1996, o denominado de Leniency Notice, que de forma diversa do modelo americano, que concede a anistia apenas à primeira firma que trair o cartel e delatá-lo à autoridade antitruste, seguiu uma abordagem de escalonamento das multas, conforme aponta Rodas (2007), de modo que a primeira empresa que se apresentar e contribuir com as investigaçóes que levem a comprovação do cartel terá maiores benefícios, mas isso não impede que outras empresas participantes venham contribuir para acabar com o cartel.

De acordo com o Jornal Oficial das Comunidades Europeias (1996), a não aplicação da pena ou redução ocorrerá quando uma empresa: (a) for a primeira a trair e a delatar o cartel antes de qualquer investigação, apresentando informaçóes úteis com toda documentação e provas, o que lhe garantirá uma redução da multa na ordem de 75 a 100\% do valor total; (b) for a primeira a trair e a delatar o cartel, mas a investigação já estiver em curso, a redução da multa será em torno de 50 a 75\% do valor total; e (c) se não for a primeira a trair e a delatar o cartel, mas colaborar com a investigação e não contestar as alegaçóes de que é alvo, garantirá para si uma redução da multa que pode ser de $10 \%$ a $50 \%$ do valor total. A exata redução do valor das multas fica sob a discricionariedade da Comissão Europeia.

Em 2002, seguindo diretrizes do modelo norte-americano, a Comunidade Europeia promoveu uma reforma no Leniency Notice, ampliando a transparência e ofertando maiores garantias nas condiçóes de concessão de eventuais reduçóes das penas aos membros de cartéis que buscam os acordos. Essa reforma possibilitou a redução de pena para as empresas colaboradoras, que fazem parte do cartel (chamados latecomers), ainda que as investigaçóes já tenham sido iniciadas, desde que:

(i) ofereçam provas contundentes acerca da existência do cartel; (ii) aceitem cooperar com o órgão antitruste de forma irrestrita; (iii) abandonem, definitivamente, as antigas condutas ilícitas; (iv) não tenham forçado a participação de quaisquer empresas no cartel. A anistia total, nos casos em que a investigação já tenha sido iniciada, somente será possível se a empresa for a primeira a cooperar com as autoridades antitruste, a fim de delatar evidências suficientes do cartel (RODAS, 2007, p. 25).

Os latecomers se beneficiam do programa com uma redução escalonada das penalidades, desde que atendam os requisitos cumulados descritos acima. Para o primeiro latecomers, 
redução de 30 a 50\%; ao segundo redução de 20 a 30\%; e aos demais membros do cartel, redução de até 20\% (Jornal Oficial das Comunidades Europeias, 2002 - item 23).

O programa europeu, Leniency Notice, passou por uma nova revisão em 2006 e a principal alteraçáo foi a inclusão da possibilidade de o candidato a leniente continuar participando do cartel, na medida da necessidade para preservar a integridade e confidencialidade das negociaçôes do acordo de leniência (Jornal Oficial das Comunidades Europeias, 2006 - item 12 b).

No período de 2011 a fevereiro de 2015 o Tribunal de Justiça Europeu já aplicou multas que totalizam $€ 6.077 .179 .000$, conforme se observa no gráfico 01 , a seguir.

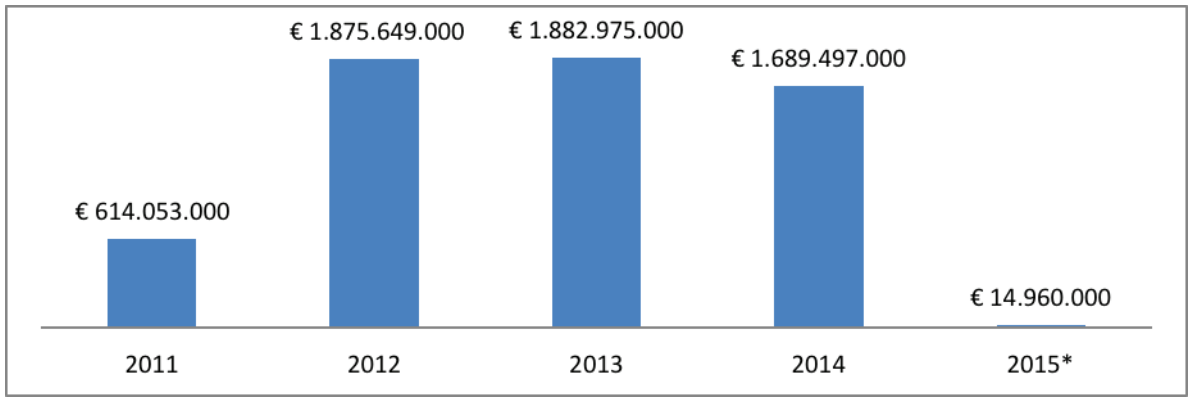

Gráfico 02- Multas impostas a cartéis pela Corte de Julgamento Europeia no período entre 2011 a 2015 , valores em $€$ (Euros).

Fonte: European Comission, 2015.

* Valor corresponde até o mês de fevereiro de 2015.

\subsection{Programa de Leniência no Brasil.}

O programa de leniência somente foi instituído pela Medida Provisória no 2.055, de 11 de agosto de 2000 que, após três ediçôes, foi convertida na Lei no 10.149/2000, alterando e acrescentando dispositivos à então lei de defesa da concorrência (Lei no 8.884/94), especificamente os artigos 35-B e 35-C, que passaram a regular os acordos de leniência, com a principal finalidade de combater os delitos de cartéis, com a colaboração do co-autor do delito em troca de benefícios.

Segundo Mello et al (2008, p. 587), o Brasil, ao instituir o acordo de leniência, "optou pela consensualidade que, na medida do possível, deve operar na Administração Pública com vista à otimização da investigação antitruste de forma a proteger os interesses tutelados pela ordem econômica, bem como repreender os atos que expressam o abuso do poder econômico":

[...] a Lei no 8.884/94 reconhece que é do interesse dos consumidores brasileiros conceder benefícios àquele participante de cartel que queira 
por um fim na conduta e cooperar de forma plena e ampla com as autoridades de defesa da concorrência de modo a permitir a condenação dos demais participantes do cartel. $\mathrm{O}$ interesse dos cidadáos brasileiros de ver desvendados e punidos carteis supera o interesse de sancionar uma única empresa ou indivíduo que possibilitou a identificação, desmantelamento e punição de todo o cartel (SDE/CADE - Secretaria de Direito Econômico, Ministério da Justiça Conselho Administrativo de Defesa Econômica, 2009, p. 17).

A Portaria do Ministério da Justiça no 456, de 15 de março de 2010, que trata de diversas espécies de processos administrativos ${ }^{2}$, e que também regulamenta o Programa de Leniência, considera este um "[...] instrumento fundamental para garantir a plena concretização do princípio constitucional da livre concorrência, com especial relevância para a implementação da Política Brasileira de Combate a Carteis” (BRASIL, 2010).

Em 2011 a legislação de defesa da concorrência sofreu significativas alteraçóes, com a aprovaçáo da Lei no 12.529 , de 30 de novembro de 2011, que revisou todo o Sistema Brasileiro de Defesa da Concorrência (SBDC).

O modelo vigente até 2011 tinha como problema impedir a empresa líder do cartel de celebrar o acordo de leniência, mas, com a reforma, esse impedimento foi retirado. Essa alteração parte da própria dificuldade de se avaliar quem é o líder, bem como de ampliar meios de prova oferecida pela empresa que se encontra nessa posição:

A SDE reconhece que em muitos carteis não é possível identificar facilmente seu líder. $\mathrm{O}$ mero fato de uma empresa ter agendado uma reunião ou mantido arquivos do cartel não necessariamente a desabilita como potencial beneficiária do Acordo de Leniência. Além disso, não haverá um líder do cartel se duas ou mais partes desempenharam papéis equivalentes no funcionamento da prática, nenhuma tendo se sobressaído em sua organização. Por fim, o fato de uma empresa ser a líder de mercado não significa, necessariamente, que seja a líder do cartel (BRASIL, 2004, p. 45).

2 Art. 10 Regulam-se por esta Portaria as diversas espécies de processos administrativos previstos na Lei No 8.884, de 11 de junho de 1994, com a redação dada pela Lei No 9.021, de 30 de março de 1995, Lei No 9.470, de 10 de julho de 1997, pela Lei No 10.149, de 21 de dezembro de 2000, e pela Lei No 11.482, de 31 de maio de 2007, para apuração, prevenção ou repressão de infraçóes contra a ordem econômica, no âmbito da Secretaria de Direito Econômico:

I - Processo Administrativo para aprovação de Ato de Concentraçáo Econômica;

II - Procedimento Administrativo para Apuração de Ato de Concentração;

III - Procedimento Administrativo Preparatório;

IV - Averiguação Preliminar para apuração de indícios de infração contra a ordem econômica;

$\mathrm{V}$ - Processo Administrativo cuja investigação possa resultar na imposição de sançóes administrativas por infração contra a ordem econômica; e

VI - Processo Administrativo para imposição de sançôes processuais incidentais. 
Considerando a possibilidade de empresas participarem de mais de um grupo cartelizado, o SBDC também instituiu, aos moldes do modelo norte-americano, a possibilidade da leniência plus, que ocorre quando uma empresa já sob investigação, queira contribuir na investigação de um segundo cartel da qual é participante que ainda não está sob investigação. Nesta situação, embora o infrator não possa celebrar um acordo, se beneficiará da redução de $1 / 3$ da pena que lhe for aplicada no primeiro cartel investigado e a extinção da ação punitiva em relação à nova infração denunciada, conforme disposição do art. $86 \$ \$ 7^{\circ}$ e $8^{\circ}$, da Lei ${ }^{\circ} 12.529$ de 2011.

$\$ 7^{\circ} \mathrm{A}$ empresa ou pessoa física que não obtiver, no curso de inquérito ou processo administrativo, habilitação para a celebração do acordo de que trata este artigo, poderá celebrar com a Superintendência-Geral, até a remessa do processo para julgamento, acordo de leniência relacionado a uma outra infração, da qual o Cade não tenha qualquer conhecimento prévio.

$\$ 8^{\circ} \mathrm{Na}$ hipótese do $\$ 7 \mathrm{o}$ deste artigo, o infrator se beneficiará da redução de $1 / 3$ (um terço) da pena que lhe for aplicável naquele processo, sem prejuízo da obtenção dos benefícios de que trata o inciso I do $\$ 40$ deste artigo em relação à nova infração denunciada.

Contudo, para a obtenção deste benefício, o leniente precisa denunciar o segundo cartel antes que o primeiro seja levado ao CADE para julgamento final.

A leniência plus tem como objetivo estimular empresas e pessoas investigadas a considerarem a possibilidade de celebrar acordo de leniência com relaçáo a todos os seus mercados de atuação.

\subsubsection{Requisitos e Benefícios do Programa de Leniência}

O programa de leniência consiste na celebração de acordos entre o CADE (por meio de sua Superintendência-Geral) e os agentes econômicos envolvidos na prática de carteis, que buscam se desvincular dos conluios e obter benefícios do programa, visando extinguir a punibilidade administrativa e criminal ou a redução da penalidade aplicável.

Mas, para celebrar o acordo, a Lei no 12.529/2011 estabelece algumas condiçóes, conforme rege o art. 86, incisos I e II, como a colaboração efetiva com as investigaçôes e com o processo administrativo, na "identificação dos demais envolvidos na infração" e na “obtenção de documentos que comprovem a infração noticiada ou sob investigação". Além destas condiçóes, para celebrar o acordo de leniência, a empresa integrante do cartel deve preencher, cumulativamente os requisitos do art. $86, \$ 1^{\circ}$ e incisos, da lei supra, in verbis:

$\$ 1^{\circ} \mathrm{O}$ acordo de que trata o caput deste artigo somente poderá ser celebrado se preenchidos, cumulativamente, os seguintes requisitos: 
I - a empresa seja a primeira a se qualificar com respeito à infração noticiada ou sob investigação;

II - a empresa cesse completamente seu envolvimento na infração noticiada ou sob investigação a partir da data de propositura do acordo;

III - a Superintendência-Geral não disponha de provas suficientes para assegurar a condenação da empresa ou pessoa física por ocasião da propositura do acordo; e

IV - a empresa confesse sua participação no ilícito e coopere plena e permanentemente com as investigaçóes e o processo administrativo, comparecendo, sob suas expensas, sempre que solicitada, a todos os atos processuais, até seu encerramento.

$\mathrm{O}$ acordo de leniência não é apenas para pessoas jurídicas, pessoas físicas também poderão celebrar acordos de leniência (art. 86, $\$ 2^{\circ}$ ), desde que cumpram os requisitos II, III e IV, do art. 86, $\$ 1^{\circ}$ da Lei no $12.529 / 2011$.

Conforme estipula o dispositivo legal, para atender os requisitos do acordo de leniência, o (a) proponente (empresa ou pessoa física) deve ser o primeiro a se apresentar à Superintendência-Geral e a confessar sua participaçáo na prática denunciada. A ordem de apresentação é regulada por meio de um sistema de senhas (marker system), que náo se aplica para a leniência individual, o que permite que todos os agentes de uma mesma sociedade se beneficiem deste instituto:

A SDE pode conceder uma senha (“marker system”) para proteger a posição de um candidato na "fila" para o Acordo de Leniência por um período de não mais de 30 dias, de modo a lhe permitir obter as informaçóes e provas necessárias sobre a conduta denunciada. Para se habilitar para a senha, o candidato deve fornecer à SDE informaçốes a respeito de seu nome e endereço, os co-partícipes do cartel ("quem”), os bens e locais afetados ("o quê" e "onde") e, se possível, a duração estimada do cartel ("quando"). O candidato deve informar também sobre outras propostas de Acordo de Leniência sobre a mesma prática apresentadas ou a serem apresentadas a outras jurisdiçóes (SDE/ CADE, 2009, p. 21).

Quando a empresa se habilita no programa de leniência, é garantido também aos funcionários envolvidos o mesmo benefício, desde que assinem o acordo de leniência juntamente com a empresa e atendam aos requisitos legais. Entretanto, se a empresa náo aderir ao programa, seu funcionário pode fazê-lo individualmente, mas a proteção não será estendida à empresa, conforme disposição do art. 191, $\$ 3^{\circ}$, do RICADE.

O leniente deve também cessar seu envolvimento na atividade ilícita, que de acordo com Taufick (2012, p. 398), trata-se da "cessação do comprometimento com o cartel", 
entretanto, é possível que a continuidade da conduta seja necessária para não levantar suspeitas e servir de oportunidade para coletar provas contra outros membros do cartel em uma operação de busca e apreensão.

Entretanto, para celebrar o acordo de leniência a Superintendência-Geral do CADE, não pode dispor de elementos probatórios suficientes para ensejar a condenação do proponente, conforme indica o inciso III do $\$ 1^{\circ}$ do art. 86 , bem como o art. $199, \$ 1^{\circ}$, XI e XII do RICADE, dado que o acordo visa conceder a extinção da ação punitiva, em casos em que o CADE não tenha possibilidade de constituir um acervo de provas apto à condenação do proponente.

Destarte para obter os benefícios do programa de leniência, deve haver a confissão do crime, pois se não há confirmação do crime, não há punição a ser extinta. Assim, além da confissáo, o candidato a leniente precisa cooperar permanentemente com as investigaçôes e o processo administrativo até o seu encerramento.

A proposta de acordo de leniência pode ser oral ou escrita - art. 193, RICADE -, mas da proposta, apresentada oralmente à Superintendência-Geral, será elaborado um termo único, e, tanto uma quanto a outra terão tratamento sigiloso.

$\mathrm{O}$ art. 197 do RICADE estabelece os prazos para negociação da proposta de acordo de leniência, que é de 6 (seis) meses, prorrogáveis por outros 6 (seis) meses, a critério da Superintendência-Geral, caso estejam presentes circunstâncias extraordinárias. Apenas o Superintendente-Geral e seu Gabinete participam na fase de negociação. Se nenhum acordo for celebrado, todos os documentos referentes à negociação são devolvidos à parte.

Se a proposta for rejeitada ou o proponente vier a desistir do acordo de leniência, o que pode ser realizado a qualquer momento antes da assinatura do respectivo instrumento de acordo, as informaçóes apresentadas não poderão ser utilizadas pelo CADE. Entretanto, o CADE poderá iniciar procedimento investigativo no âmbito da Superintendência-Geral para apurar os fatos relacionados à proposta de acordo de leniência, conforme disposição do art. 198 do RICADE.

Atendidos os requisitos e uma vez declarado o cumprimento do acordo de leniência pelo Tribunal, o signatário fará jus aos benefícios previstos no art. $86, \$ 4^{\circ}$, I e II, da Lei $\mathrm{n}^{\circ} 12.529$ de 2012 e do art. 201 do RICADE.

Art. 201. Uma vez declarado o cumprimento do acordo de leniência pelo Cade, será decretada em favor do signatário do acordo de leniência:

I - a extinção da ação punitiva da administração pública, nas hipóteses em que a proposta do acordo de leniência tiver sido apresentada à Superintendência-Geral sem que essa tivesse conhecimento prévio da infração noticiada; ou 
II - nas demais hipóteses, a redução de um a dois terços das penas aplicáveis na seara administrativa.

Parágrafo único. Nas duas hipóteses referidas acima, extingue-se automaticamente a punibilidade dos crimes tipificados na Lei no 8.137, de 27 de novembro de 1990, e nos demais crimes diretamente relacionados à prática de cartel, tais como os tipificados na Lei no 8.666, de 21 de junho de 1993 e os tipificados no art. 288 do Decreto-Lei no 2.848 , de 7 de dezembro de 1940.

Conforme artigos 86 e 87, da Lei no 12.529/2011, o acordo de leniência garante aos dirigentes e administradores da empresa beneficiária a imunidade na esfera administrativa e criminal. A lei determina, ainda, a suspensão do curso do prazo prescricional e impede o oferecimento de denúncia criminal contra tais pessoas físicas.

O primeiro acordo de leniência celebrado no Brasil deu-se em 8 de outubro de 2003, após a realização de duas operaçóes de busca e apreensão, um dos membros de cartel apresentou-se à SDE (Secretaria de Direitos Econômicos) para delatar às autoridades antitruste um esquema elaborado por um grupo de 21 empresas, três entidades e 30 pessoas físicas do setor de segurança privada do Rio Grande do Sul para fraudar licitaçóes e combinar preços. Visando a obtenção e imunidade total das multas administrativas e das sançóes criminais, o beneficiário do programa de leniência apresentou provas diretas das fraudes às licitaçóes, incluindo testemunhos de empregados e documentos trocados entre os integrantes do cartel (SEAE, 2009). Com a comprovação, inquéritos criminais foram instaurados contra as pessoas físicas envolvidas no cartel, com exceção do beneficiário do acordo de leniência. E, em 2007, como resultado do processo o Cade:

[...] impôs multas que variaram de 15 a $20 \%$ do faturamento bruto de 2002 a 16 empresas pela prática de cartel. Administradores das empresas condenadas e três associaçôes de classe também foram condenados e multados pelo CADE. As multas impostas foram superiores a $\mathrm{R} \$ 40$ milhões. Na mesma ocasiáo, o CADE reconheceu que o beneficiário do Programa de Leniência cumpriu as condiçóes impostas no Acordo e, portanto, nenhuma sanção lhe foi imposta na esfera administrativa, tendo havido ainda a extinção automática da punibilidade no âmbito criminal (SEAE, 2009, p.19).

Embora o programa de leniência seja recente no SBDC, ele tem sido extremamente importante para os esforços de combate a carteis. Segundo o CADE, no período compreendido entre 2003 a 2014, foram realizados 40 acordos leniência e nove aditivos a acordos de leniência, conforme indica a distribuição anual no gráfico 03, o que demonstra avanços e o reconhecimento do programa de leniência como instrumento de defesa da concorrência. 


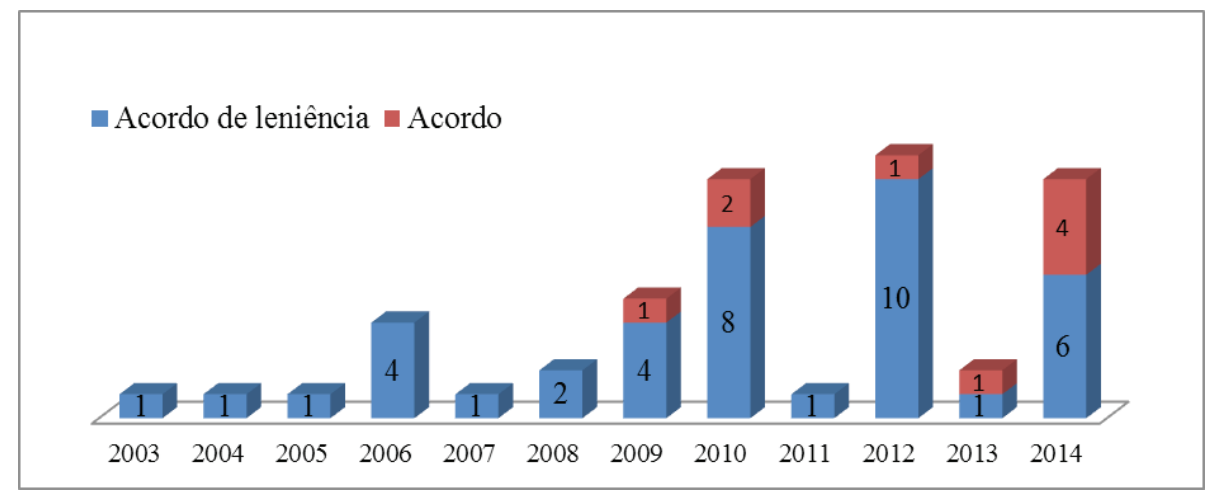

Gráfico 03-Acordos de leniência e aditivos assinados no período de 2003 a 2014. Fonte: Cade, 2015.

A partir dos valores arrecadados é possível quantificar a grandeza das sançôes impostas pelo CADE, no período de 2009 a setembro de 2014, quando arrecadou $\mathrm{R} \$$ 288.375.130, conforme demonstra os dados do gráfico 04 . Merece destaque o aumento de 66,74\% dos valores arrecadados entre 2011 e 2013, justamente o período da nova lei que criou regras mais claras para a celebração de acordos de leniência. Estes valores indicam uma maior eficiência da norma e a atuaçăo do CADE, que com mais transparência e aplicação de multa pode estimular os acordos de leniência.

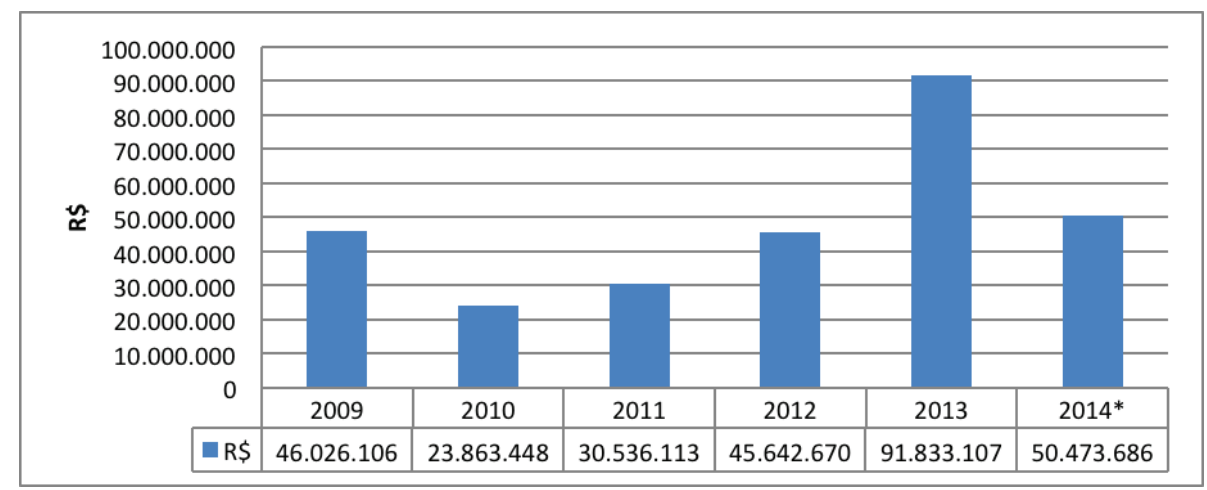

Gráfico 04- Valores arrecadados no período de 2003 a 2014, valores em Reais.

* Valores até setembro de 2014.

Fonte: Cade, 2014.

Segundo Rodas (2007, p. 23), um programa eficaz de leniência deve criar incentivos suficientes para que a empresa conclua que terá mais benefícios denunciando a prática de cartel do que se silenciar, para isso, é importante conter os seguintes elementos: “i) nível 
das sançóes, ii) receio da descoberta, iii) incerteza da conduta do concorrente integrante do acordo, iv) transparência no aplicação do programa”.

O aperfeiçoamento da legislação antitruste ganha importância diante do constante avanço da internacionalização das economias nacionais e a transnacionalização das empresas, que produzem mudanças em práticas comerciais que ampliam as possibilidades de operaçôes formadoras de carteis, exigindo-se mecanismos diferenciados na defesa da concorrência.

Embora os programas de leniência do Brasil e da Comunidade Europeia tenham tomando como ponto de partida as experiências do modelo norte-americano, há algumas diferenças importantes, que estão destacadas no quadro 01 , a seguir:

\section{Quadro: 01- Características diferenciais do modelo norte americano, europeu e brasileiro em programas de leniência}

\begin{tabular}{|c|c|c|c|}
\hline \multirow{2}{*}{ Caraterísticas } & \multicolumn{3}{|c|}{ Programas de leniência } \\
\hline & Norte-americano & Europeu & Brasileiro \\
\hline $\begin{array}{l}\text { Imunidade } \\
\text { após o } \\
\text { começo das } \\
\text { investigaçóes }\end{array}$ & $\begin{array}{l}\text { Sim, desde que seja } \\
\text { a primeira empresa } \\
\text { - imunidade da } \\
\text { multa e do processo } \\
\text { criminal. }\end{array}$ & $\begin{array}{l}\text { Sim, desde que seja } \\
\text { a primeira empresa. }\end{array}$ & $\begin{array}{l}\text { Sim, apenas para o } \\
\text { processo criminal. }\end{array}$ \\
\hline $\begin{array}{c}\text { Redução de } \\
\text { multas para } \\
\text { as empresas } \\
\text { que náo } \\
\text { atenderam os } \\
\text { requisitos do } \\
\text { programa }\end{array}$ & $\begin{array}{l}\text { Não há previsão de } \\
\text { escalonamentos da } \\
\text { multa para novas } \\
\text { empresas que vierem } \\
\text { a delatar a formação } \\
\text { de cartel }\end{array}$ & $\begin{array}{l}\text { A empresa que náo } \\
\text { for a primeira a } \\
\text { delatar a formação } \\
\text { do cartel poderá se } \\
\text { beneficiar com uma } \\
\text { redução de multa de } \\
\text { forma escalonada }\end{array}$ & $\begin{array}{c}\text { Náo há previsão } \\
\text { de escalonamentos } \\
\text { da multa para } \\
\text { novas empresas que } \\
\text { vierem a delatar a } \\
\text { formaçáo de cartel, } \\
\text { mas há a leniência } \\
\text { plus. }\end{array}$ \\
\hline Penalidade & $\begin{array}{l}\text { Os infratores estão } \\
\text { sujeitos à aplicaçãáo } \\
\text { de sançóes, tão } \\
\text { logo investigados e } \\
\text { condenados. }\end{array}$ & $\begin{array}{c}\text { A Comissão } \\
\text { Europeia não tem } \\
\text { jurisdiçáo sobre } \\
\text { as pessoas, cabe a } \\
\text { cada um dos países } \\
\text { membros aplicarem } \\
\text { a punição e/ou } \\
\text { multa. }\end{array}$ & $\begin{array}{l}\text { Os infratores estão } \\
\text { sujeitos à aplicaçáo } \\
\text { de sançóes, tão } \\
\text { logo investigados e } \\
\text { condenados. }\end{array}$ \\
\hline
\end{tabular}




\begin{tabular}{|c|c|c|c|}
\hline \multirow{2}{*}{ Caraterísticas } & \multicolumn{3}{|c|}{ Programas de leniência } \\
\hline & Norte-americano & Europeu & Brasileiro \\
\hline $\begin{array}{c}\text { Persecução } \\
\text { Civil }\end{array}$ & $\begin{array}{l}\text { Previsão da cláusula } \\
\text { de restituição } \\
\text { (restitution clause), } \\
\text { concernente à } \\
\text { obrigação da } \\
\text { empresa beneficiada } \\
\text { pela anistia } \\
\text { indenizar as partes } \\
\text { prejudicadas. }\end{array}$ & $\begin{array}{c}\text { Cada país } \\
\text { membro tem a } \\
\text { responsabilidade } \\
\text { de regulamentar as } \\
\text { consequências civis, } \\
\text { como reparaçáo/ } \\
\text { indenização sobre os } \\
\text { lenientes. }\end{array}$ & $\begin{array}{l}\text { Possibilidade Açáo } \\
\text { Cível Pública, para } \\
\text { ressarcimento de } \\
\text { perdas e danos } \\
\text { gerados pelo cartel. }\end{array}$ \\
\hline $\begin{array}{l}\text { Cartel como } \\
\text { ato criminoso }\end{array}$ & Sim & Não & Sim \\
\hline
\end{tabular}

Fonte: Elaboração própria.

Como é possível observar o sistema brasileiro optou por retirar dos modelos americano e europeu seus aspectos mais positivos o que o torna, ao menos a priori, mais eficiente que os outros dois.

\section{Reflexos do Acordo de Leniência no Direito Civil e Penal}

A tutela administrativa do Estado visando proteger a defesa da concorrência não esgota a possibilidade de açóes individuais ou coletivas em face dos infratores à ordem econômica para promover o ressarcimento por prejuízos gerados aos consumidores e ou ao poder público.

$\mathrm{Na}$ Uniāo Europeia e na legislação norte-americana, o fato de uma empresa ter cooperado com a Comissão durante o seu procedimento administrativo e ter obtido imunidades das penas ou redução não as protege das consequências de direito civil.

A legislação brasileira também proporciona mecanismos que permite que os consumidores que foram de forma prejudicados, possam ingressar com açóes visando à reparação de danos.

\subsection{Da Reparação Civil}

A legislação brasileira permite a busca da reparação dos danos. Assim, além da persecução administrativa e penal, os membros de carteis estão sujeitos ainda à persecução na esfera civil, conforme art. 47 da Lei no 12.529/2011, que "prevê que consumidores 
podem ingressar em juízo, diretamente ou por meio de associações, Ministérios Públicos e PROCONs, para obter indenização por perdas e danos sofridos pela prática de cartel”.

Tal dispositivo, segundo Taufick, é relevante, pois possibilita ações paralelas em função de danos à concorrência, contudo, é preciso reconhecer a pouca tradição brasileira nesse tipo de reparaçáo, cujo aumento depende "da paulatina educação dos cidadáos pela advocacia da concorrência - a qual é importantíssimo instrumental de desincentivo ao cometimento de ilícitos concorrenciais" (2012, p. 293).

Além da lei anticoncorrencial não excluir a reparação pelos danos, essa sistemática encontra reforço no Código de Defesa do Consumidor, que, no seu art. $6^{\circ}$, estabelece o direito a reparação de danos patrimoniais e morais como um direito básico do consumidor:

[...] VI - a efetiva prevenção e reparação de danos patrimoniais e morais, individuais, coletivos e difusos; VII - o acesso aos órgãos judiciários e administrativos com vistas à prevenção ou reparação de danos patrimoniais e morais, individuais, coletivos ou difusos, assegurada a proteção Jurídica, administrativa e técnica aos necessitados; [...].

O disposto no art. 47, da Lei no 12.529/2011, combinado com o art. 82 da Lei $n^{\circ}$ 8.078/1990, estabelece o rol de legitimados para o ingresso das açóes coletivas, visando à proteção dos direitos difusos, coletivos e individuais homogêneos.

Art. 82. Para os fins do art. 81, parágrafo único, são legitimados concorrentemente: (Redação dada pela Lei no 9.008, de 21.3.1995)

I - o Ministério Público,

II - a União, os Estados, os Municípios e o Distrito Federal;

III - as entidades e órgãos da Administração Pública, direta ou indireta, ainda que sem personalidade jurídica, especificamente destinados à defesa dos interesses e direitos protegidos por este código;

IV - as associaçóes legalmente constituídas há pelo menos um ano e que incluam entre seus fins institucionais a defesa dos interesses e direitos protegidos por este código, dispensada a autorização assemblear.

$\$ 1^{\circ} \mathrm{O}$ requisito da pré-constituição pode ser dispensado pelo juiz, nas açóes previstas nos arts. 91 e seguintes, quando haja manifesto interesse social evidenciado pela dimensão ou característica do dano, ou pela relevância do bem jurídico a ser protegido.

A legitimidade para agir expressada por esse artigo possibilita que quaisquer dos entes elencados atuem independentemente da concordância dos demais na interposição das açóes coletivas. Nesse sentido, Nunes (2010, p. 796), entende que a norma protecionista do direito de ação é conferida a entes legitimados de forma concorrente, conferindo maior garantia de proteção aos direitos estabelecidos, visando ampliar a eficácia da lei. 
Com o objetivo de estimular e promover o ajuizamento de açóes privadas pelas vítimas de cartel, principalmente pela via de ação cível pública, o conselheiro Fernando Furlan, no cartel dos gases medicinais, determinou em seu voto no Processo Administrativo 08012.009888/2003-70 (item 7.3), que as entidades prejudicadas pelo cartel fossem informadas da possibilidade de promover açóes de reparação por perdas e danos, bem como da divulgação dos documentos.

Com possibilidade de responsabilização civil por perdas e danos, em março de 2012 a Procuradoria da República em Campinas ajuizou ação civil pública, para que as empresas condenadas pelo CADE por formação de cartel na comercialização de gases industriais e medicinais, sejam obrigadas a ressarcir os cofres públicos pelos prejuízos causados ao Sistema Único de Saúde (SUS) e aos órgãos públicos que compraram gases industriais superfaturados na Subseção Judiciária de Campinas ${ }^{3}$.

\subsection{Reflexos Penais do Acordo de Leniência}

A livre concorrência e a livre iniciativa, previstas no caput do art. 170 da Constituição, são fundamentos basilares da ordem econômica. Desta forma, ações que coloquem em risco ou efetivamente violam os bens jurídicos do sistema econômico-social estarão sujeitas à punição pelo Estado, enquanto crimes contra a ordem econômica.

Neste sentido, reconhecendo a necessidade de um controle eficaz em relação à criminalidade moderna Hassemer apud Bitencourt (2013, p. 445) sugere a criação de um novo direito, denominado Direito de Intervenção, que seria um meio termo entre o Direito Penal e o Direito Administrativo, sem as pesadas sançóes do Direito Penal, especialmente a pena privativa de liberdade, mas que seja tão eficaz e possa ter, ao mesmo tempo, garantias menores que a do Direito Penal tradicional.

Segundo Bittencourt (2013, p. 875), “a pena não é elemento do crime, mas consequência deste. A punição é consequência natural da realização da ação típica, antijurídica e culpável. Porém, após a prática do fato delituoso podem ocorrer causas que impeçam a aplicação da sanção respectiva”, conforme disposição do art. 107 do Código Penal, que apresenta um rol de situaçôes que levam a extinção da punibilidade.

O rol previsto no artigo supra descrito não é numerus clausus, haja vista outros dispositivos, como por exemplo, perdão judicial (arts. $121, \$ 5^{\circ} ; 129, \S 8^{\circ} ; 180, \$ 3^{\circ} ; 181$;

3 Municípios da 5a Subseção Judiciária do Estado de São Paulo: Águas de Lindóia, Amparo, Arthur Nogueira, Cajamar, Campinas, Campo Limpo Paulista, Capivari, Conchal, Cosmópolis, Elias Fausto, Engenheiro Coelho, Holambra, Hortolãndia, Indaiatuba, Itatiba, Itupeva, Jaguariúna, Jarinu, Jundiaí, Lindóia, Louveira, Mombuca, Monte Alegre do Sul, Monte Mor, Morungaba, Paulínia, Pedreira, Rafard, Santo António da Posse, Serra Negra, Socorro, Sumaré, Valinhos, Várzea Paulista e Vinhedo. 
348, $\$ 2^{\circ}$; do Código Penal); a restitutio in integrum (art. 249, $\$ 2^{\circ}$ ); as hipóteses do art. $7^{\circ}, \$ 2^{\circ}, b$ e $e$, do Código Penal.

De qualquer modo, a causa extintiva de punibilidade, segundo Nucci (2006, p.481), "é o desaparecimento da pretensão punitiva ou executória do Estado em razão de específicos obstáculos previstos em lei”. Em complemento, Bittencourt (2013, p.875), diz que o que "cessa é a punibilidade do fato, em razão de certas contingências ou por motivos vários de conveniência ou oportunidade política”.

Assim, o dispositivo em questáo pode ser compreendido como outro efeito penal do acordo de leniência, pois, quando da "declaração de seu cumprimento, o Estado se despoja do poder de punir o leniente, que se livre da imposição de penalidades dos crimes econômicos denunciados" (TAVARES; GIACAGLIA, 2010, p. 90). Nota-se, portanto, que não há a extinção do crime em si, mas do jus puniendi do Estado perante o leniente.

Taufick (2012, p. 413) avalia que atual legislação de defesa da concorrência fortaleceu o programa de leniência ao prever não apenas os crimes contra a ordem econômica da Lei no 8.137/1990, incorporando "adicionalmente, quaisquer crimes relacionados à prática de cartel" e estendendo os seus efeitos para crimes conexos ao cartel como, por exemplo, fraude a licitação pública, conforme demonstra a redação do art. 87 da Lei no $12.529 / 2011$.

Nos crimes contra a ordem econômica, tipificados na Lei no 8.137, de 27 de dezembro de 1990, e nos demais crimes diretamente relacionados à prática de cartel, tais como os tipificados na Lei no 8.666, de 21 de junho de 1993, e os tipificados no art. 288 do Decreto-Lei no 2.848, de 7 de dezembro de 1940 - Código Penal, a celebraçáo de acordo de leniência, nos termos desta Lei, determina a suspensão do curso do prazo prescricional e impede o oferecimento da denúncia com relação ao agente beneficiário da leniência.

Parágrafo único. Cumprido o acordo de leniência pelo agente, extinguese automaticamente a punibilidade dos crimes a que se refere o caput deste artigo.

Ainda segundo Taufick (2012, p. 413), a abrangência do acordo de leniência quer evitar que "a extinção da punibilidade prevista na lei fosse irregularmente contornada pelas autoridades públicas, em especial membros do Ministério Público, os quais astutamente tentavam forçar a punição do cartel, tipificando-o como formação de quadrilha" ${ }^{4}$, conforme previsto no art. 288 do Código Penal.

4 A Lei 12.850 de 2013, alterou a redação do art. 288 do Código Penal, de acordo com a vigente, a associação de 3 ou mais pessoas para o fim específico de cometer crime passa a ser denominado de associação criminosa. 
Neste sentido, o acordo de leniência, encontra semelhança na delação premiada, que foi instituído no ordenamento jurídico brasileiro, por meio da Lei no 9.807/1999, que traz a possibilidade da extinção da punibilidade ou redução da pena em compensação à efetiva e voluntária colaboração do acusado com a investigação e o processo criminal.

\section{Preocupações Éticas no Acordo de Leniência}

Constitucionalmente cabe ao Estado a responsabilidade de prevenir e repreender infrações contra a ordem econômica, uma função essencial para garantir os seus princípios, o que enseja o desenvolvimento de institutos legislativos, pautados em diretrizes éticas, bem como a criação de órgãos especializados na prevenção, repressão e coerção contra as ações criminosas relativas à concorrência.

A legislação brasileira, com a finalidade de reprimir infraçóes à ordem econômica, incentiva o acordo de leniência, contudo, sua utilização traz alguns questionamentos do ponto de vista ético, por exemplo, para combater o crime é necessária a associação criminosa? Mesmo sendo legal o acordo de leniência é um instituto ético?

O termo delação advém do latim delatione e significa "denunciar, revelar (crime ou delito); acusar como autor de crime ou delito; deixar perceber; denunciar como culpado; denunciar-se como culpado; acusar-se" (FERREIRA, 1999, p. 617).

Para uma parcela da doutrina, a delação premiada é um incentivo legal à traição, pois o delator concorda voluntariamente em trair os demais membros da prática criminal, com a finalidade de receber benefícios da redução ou extinção da pena, o que somente torna ainda mais evidente a sua absoluta falta de padróes éticos e morais, ainda que contrários ao ordenamento jurídico.

O acordo apresenta-se como um desprezível meio de obtenção de confissão exclusivamente baseado na traição, seja pela sedução moral de obtenção dos benefícios de redução da sanção penal ou extinção da punibilidade, seja pela coação psicológica, em virtude da alta possibilidade de seu envolvimento na prática delituosa ser descoberto ou delatado por outro participante (SALOMI, 2012, p.180).

A esse respeito Damásio de Jesus (2002, p. 30-31), registra que:

A polêmica em torno da "delação premiada", em razão de seu absurdo ético, nunca deixará de existir. Se, de um lado, representa importante mecanismo de combate à criminalidade organizada, de outro, traduz-se num incentivo legal à traição. A nós, estudiosos e aplicadores do Direito, incumbe o dever de utilizá-la cum grano salis, notadamente em razão da ausência de uniformidade em seu regramento. Não se pode fazer dela um fim em si mesma, vale dizer, não podem as autoridades encarregadas 
da persecução penal contentarem-se com a "delação", sem buscar outros meios probatórios tendentes a confirmá-la.

Da mesma forma, Castelo Branco apud Salomi (2012, p.180), revelou que o instituto da delação, aplicado aqui analogicamente, apresenta, sob o ponto de vista ético, dois pesos e duas medidas, pois traz: "[...] puniçóes diferentes para procedimentos totalmente iguais, com recompensas especiais ao traidor, como se a traição fosse um valor positivo de caráter humano".

Dessa forma fica evidenciado o conflito ético do instituto com os princípios da dignidade da pessoa humana, conforme artigo $1^{\circ}$, III e das garantias da liberdade e do devido processo legal, previsto no artigo $5^{\circ}$, caput, e LIV, ambos da Constituição Federal.

Nesse contexto, a delação premiada e o acordo de leniência representam instrumentos antiéticos, cuja finalidade é a obtenção de provas, provocando uma dissociação entre Direito e Moral. Para Ramos; Souza (2013, p.196) "a relativização da moral presente na sociedade pós-moderna não pode ser admitida na política estatal de combate à criminalidade".

Se considerarmos que a norma jurídica de um Estado de Direito é o último refúgio do seu povo, no sentido de que as proposiçóes enunciativas nela contidas representam um parâmetro de organização ou conduta das pessoas, definindo os limites de suas atuaçóes, é inaceitável que este mesmo regramento jurídico preveja a delação premiada em flagrante incitamento à transgressão de preceitos morais intransigíveis que devem estar, em última análise, embutidos nas regras legais exsurgidas do processo legislativo (MOREIRA, 2013, p.5).

De outro lado, existem autores que defendem a leniência, como Mendroni; Farina (2013. p.171), que destacam pontos positivos do acordo de leniência.

No que toca, portanto, as consequências do acordo de leniência, a lei $12.529 / 2011$ parece ter sido bastante coerente como os movimentos mais modernos no combate à criminalidade organizada e aos "crimes de colarinho branco", buscando dar eficácia aos instrumentos de colaboração, que auxiliam no descobrimento e dissolução dos crimes, que no caso de formação de cartel, constitui-se verdadeira organizaçáo criminosa empresarial.

Embora os argumentos dos autores contrários à leniência sejam importantes, está-se diante de um caso de conflito entre valores que merecem proteção, mas em que um se sobrepóe ao outro. Assim, a defesa da concorrência, enquanto direito coletivo, justifica a existência dos acordos de leniência em detrimento das consideraçóes morais mencionadas, vez que outros valores morais importantes são violados pelos cartelizados. 
Assim, apesar do conflito ético-moral, o acordo de leniência é um instrumento fundamental para a preservação de outros princípios constitucionais, dada a realidade das relaçóes de mercado, notadamente nas economias de mercado em um mundo globalizado.

\section{Conclusões}

A dificuldade do mercado em se autorregular fez surgir o Direito Econômico, com a finalidade de mitigar as falhas de mercado e instituir a primazia do interesse econômico geral, sem suprimir a atividade lucrativa dos agentes econômicos. Assim, a Constituição estabelece as ordens jurídico-econômicas e princípios norteadores das relaçóes econômicas. As intervenções do Estado na economia, atuando na repressão às práticas que restringem a livre concorrência e a liberdade de mercado, apresentam papel fundamental para o desenvolvimento e crescimento econômico, quer seja nos momentos de maior liberdade econômica ou nos momentos de crise.

Com a finalidade de mitigar danos à concorrência, bem como as dificuldades de identificar os carteis, o SBDC adotou o programa de leniência, instituindo no ordenamento instrumento semelhante a delação premiada, o acordo de leniência.

$\mathrm{O}$ acordo de leniência estabelece algumas condições, como a colaboração efetiva com as investigaçóes e com o processo administrativo, na "identificação dos demais envolvidos na infração" e na "obtenção de documentos que comprovem a infração noticiada ou sob investigação". Cumprido os requisitos e declarado o acordo de leniência, poderá haver a extinção da ação punitiva ou redução de um a dois terços da penalidade aplicável no âmbito administrativo e, no âmbito penal extingue automaticamente a punibilidade dos crimes contra a ordem econômica. Assim, essas providências servem de incentivo aos delatores, permitindo, assim, uma proteção mais eficiente da concorrência.

Embora em termos éticos o acordo de leniência possa ser interpretado como imoral, dado que afronta o princípio da proporcionalidade ao cominar penas diferentes para os agentes envolvidos na mesma conduta criminosa, com os mesmos objetivos e o mesmo grau de culpabilidade; de outro a regulação concorrencial deve preservar e garantir o equilíbrio entre os agentes econômicos, exercendo o interesse da justiça social e conferir prioridade aos valores do trabalho humano sobre todos os demais valores da economia de mercado, com vistas à redução das desigualdades sociais, regionais, a busca do pleno emprego e do desenvolvimento nacional.

Por isso, o acordo de leniência é um instrumento adequado a perseguir tais princípios através da garantia à concorrência livre, justa e leal. 


\section{Referências}

BAGNOLE, V. Introduçáo ao direito da concorrência: Brasil - globalizaçáo - uniáo europeia - mercosul - alca. São Paulo: Editora Singular, 2005.

BITTENCOURT, Cesar Roberto. Tratado de direito penal, 4: parte especial: dos crimes contra a dignidade sexual até os crimes contra a fé pública. $7^{a}$ edição, revista e ampliada. São Paulo: Saraiva, 2013.

BRASIL. Lei no 8.078 de 11 de setembro de 1990. Dispóe sobre a proteção do consumidor e dá outras providências. Disponível em: <http://www.planalto.gov.br/ccivil_03/leis/18078.htm>. Acesso em: 14 mar. 2015.

BRASIL. Lei no 8.884 de 11 de junho de 1994. Transforma o Conselho Administrativo de Defesa Econômica (CADE) em Autarquia, dispóe sobre a prevenção e a repressão às infraçôes contra a ordem econômica e dá outras providências. Disponível em <http://www.planalto.gov.br/ccivil_03/leis/18884.htm>. Acesso em 13 mar. 2015.

BRASIL. Portaria Conjunta SEAE/SDE no 50, de 01 de agosto de 2001.

BRASIL. Projeto de lei no 3.937, de 2004. Disponível em: < http:/www.camara.gov.br/ sileg/integras/569964.pdf>. Acesso em 13 mar. 2015.

BRASIL. Portaria no 456, de 15 de março de 2010. Disponível em: <http://www.cade. gov.br/upload/2010PortariaMJ456.pdf>. Acesso em 13 mar. 2015.

BRASIL. Lei no 12.529 de 30 de novembro de 2011. Estrutura o Sistema Brasileiro de Defesa da Concorrência; dispóe sobre a prevenção e repressão às infraçôes contra a ordem econômica; altera a Lei no 8.137, de 27 de dezembro de 1990, o Decreto-Lei no 3.689, de 3 de outubro de 1941 - Código de Processo Penal, e a Lei no 7.347, de 24 de julho de 1985; revoga dispositivos da Lei no 8.884, de 11 de junho de 1994, e a Lei no 9.781, de 19 de janeiro de 1999; e dá outras providências. Disponível em: <http://www.planalto.gov.br/ccivil_03/_Ato2011-2014/2011/Lei/L12529.htm>. Acesso em: 14 fev. 2015.

BRASIL. Resoluçáo no 1, de 29 de maio de 2012. Aprova o regimento interno do Conselho Administrativo de Defesa Econômica - RICADE. Disponível em: <http:// www.cade.gov.br/upload/Resolu\%C3\%A7\%C3\%A3o\%201_2012\%20-\%20RICADE\%20(2).pdf>. Acesso em: 9 dez. 2014.

CADE - Conselho de Administrativo de Defesa Econômica. Programa de leniência. Disponível em: <http://www.cade.gov.br/Default.aspx?fd3efe010f0d0f2b391a31>. Acesso em: 02 mai. 2015.

DEPARTMENT OF JUSTICE. Antitrust Division 2014 Criminal Enforcement Update. Disponível em: <http://www.justice.gov/atr/public/division-update/2014/criminal-program.html>. Acesso em: 01 mai. 2015. 
EUROPEAN COMMISION. Statistic. Disponível em: <http://ec.europa.eu/competition/cartels/statistics/statistics.pdf>. Acesso em: 01 mai. 2015.

FERREIRA, A. B. de H. Novo Aurélio século XXI: Dicionário da Língua Portuguesa. $3^{\text {a }}$ edição Rio de Janeiro: Nova Fronteira, 1999.

GPO - Government Publishing Office, 2004. Development organization advancement act of 2004. Disponível em: < http://www.gpo.gov/fdsys/pkg/PLAW-108publ237/ html/PLAW-108publ237.htm> Acesso em: 30 abr. 2015.

GRIFFIN, J. M. (2003). A summary overview of the antitrust division's criminal enforcement program. In: The modern leniency program after ten years. Disponível em: <http://www.usdoj.gov/atr/public/speeches/201477.htm> Data: 30/4/2015.

JESUS, D. E. de. Temas de Direito Criminal. 2 série. Saraiva: São Paulo, 2002.

JORNAL OFICIAL DAS COMUNIDADES EUROPEIAS. Sobre a não aplicação ou a reduçáo de coimas nos processos relativos a acordos, decisóes e práticas concertadas. (96/C 207/04, de 18.07.1996). Disponível em: < http://eur-lex.europa.eu/legal-content/PT/TXT/PDF/?uri=CELEX:31996Y0718(01)\&from=PT>. Acesso em: 01 mai. 2015.

JORNAL OFICIAL DAS COMUNIDADES EUROPEIAS. Comunicação da Comissão relativa à imunidade em matéria de coimas e à reduçáo do seu montante nos processos relativos a cartéis. (C 45/3, de 19.02.2002). Disponível em: <http:// eur-lex.europa.eu/LexUriServ/LexUriServ.do?uri=OJ:C:2002:045:0003:0005:PT:PDF>. Acesso em: Acesso em: 01 mai. 2015.

JORNAL OFICIAL DAS COMUNIDADES EUROPEIAS. Comunicação da Comissão Relativa à imunidade em matéria de coimas e à reduçáo do seu montante nos processos relativos a cartéis. (C 298/11, de 08.12.2006). Disponível em: <http:// eur-lex.europa.eu/LexUriServ/LexUriServ.do?uri=OJ:C:2006:298:0017:0022:PT:PDF>. Acesso em: Acesso em: 01 mai. 2015.

MELLO, S. S. de F.; et ali. Acordo de leniência: A lógica do consenso na proteçáo dos interesses difusos tutelados pela lei antitruste. In: Revista da Faculdade de Direito de Uberlândia. Uberlândia, 2008, Vol. 36, p. 575-598.

MENDRONI, M. B.; FARINA, F. M. Q.. Alteraçóes penais da nova lei do sistema brasileiro de defesa da concorrência. Revista dos Tribunais, São Paulo, v.102, n. 927, p. 159-173, jan. 2013.

MOREIRA, R.A. A delação premiada no direito brasileiro. Disponível em: <http:// www.ibadpp.com.br/wp-content/uploads/2013/04/A-dela\%C3\%A7\%C3\%A3ono-Direito-brasileiro-Romulo-Moreira.pdf?1b55ec>. Acesso em 30 abr. 2015. 
NUCCI, Guilherme de Souza. Código penal comentado. 6a Edição, revista, atualizada e ampliada. São Paulo: Editora dos tribunais, 2006.

NUNES, L. A. R. Curso de direito do consumidor: com exercícios. $5^{\text {a }}$ Edição, revisada, ampliada e atualizada. São Paulo: Saraiva, 2010.

RAMOS, F. S.; SOUZA, I. B. de. Implicaçóes éticas da delaçáo premiada na nova Lei de defesa da ordem econômica. In: Revista Pesquisas Jurídicas. vol. 2, n. ${ }^{\circ} 1$, p.184/199, jan - jun. 2013.

RIBEIRO, A.; NOVIS, M. E. Programa brasileiro de leniência: evoluçáo, efetividade e possíveis aperfeiçoamentos. In: Revista do IBRAC - Instituto Brasileiro de Estudos de Concorrência, Consumo e Comércio Internacional. São Paulo: Revista dos Tribunais, Jan. - Jun. 2010, Vol. 17, p. 147-168.

RODAS, J. G. Acordos de leniência em direito concorrencial: práticas e recomendaçóes. Revista dos Tribunais. São Paulo: Revista dos Tribunais, no 862, vol. 96, pp.22/33, agosto, 2007.

SALOMI, M. B. O Acordo de leniência e seus reflexos penais. Dissertação de Mestrado. Faculdade de Direito da Universidade de São Paulo. 2012.

SDE/CADE - Secretaria de Direito Econômico, Ministério da Justiça Conselho Administrativo de Defesa Econômica. Combate a carteis e Programa de Leniência. Coleçáo SDE/CADE no 01/2009. Disponível em: <http://www.cade.gov.br/upload/ Cartilha\%20Leniencia\%20SDE_CADE.pdf>. Acesso em: 13 mar. 2015.

TAUFICK, R. D.. Nova lei antitruste brasileira: A lei 12.529/2011 comentada e a análise prévia no Direito da Concorrência. Rio de Janeiro: Forense; São Paulo: MÉTODO, 2012.

TAVARES, C. de C.; GIACAGLIA, A. P. Efeitos do cumprimento do acordo de leniência. Análise do Inc. I do $\$ 4^{\circ}$ do art. 35-B e do art. 35-C, ambos da Lei 8.884, de 11/06/1994. In: Revista do IBRAC - Instituto Brasileiro de Estudos de Concorrência, Consumo e Comércio Internacional. São Paulo: Revista dos Tribunais, Jul.-Dez./ 2010, Vol. 18, p. 75-97. 